\title{
Revaszkularizáció vagy optimális gyógyszeres kezelés stabil koszorúér-betegségben. Melyik terápiás stratégia követendö?
}

\author{
Ágoston Gergely \\ Szegedi Tudományegyetem, Általános Orvostudományi Kar, Családorvosi Intézet, Szeged \\ Levelezési cím: Dr. Ágoston Gergely, agoston.gergely@med.u-szeged.hu
}

Az optimális gyógyszeres terápia helye stabil iszkémiás szívbetegségben továbbra is vitatott terület. Iszkémiás szívbetegségben minden beteg gyógyszeres terápiában részesül, azonban a stabil koronáriabetegek többségénél további terápiás beavatkozás, koronária-intervenció vagy bypass-mütét is történik. Az optimális gyógyszeres terápián lévő betegek revaszkularizációja számos bizonytalanságot vet fel és nem definiálható egyértelmüen annak prognosztikai jelentősége. A jelen összefoglalóban röviden ismertetjük az optimális gyógyszeres terápia jellemzőit, valamint a témában született legfontosabb multicentrikus, randomizált tanulmányok eredményeit. Következtetésként leszögezhetö, hogy az optimális gyógyszeres terápia és revaszkularizáció egyaránt alkalmazható terápiás stratégia. Hogy melyik stratégia követendő? - a kérdés megválaszolásában reményeink szerint segíteni fog a jelenleg is folyamatban lévő ISCHEMIA (International Study of Comparative Health Effectiveness with Medical and Invasive Approaches) vizsgálat, ahol a fö célkitűzés a stabil koronáriabetegek optimális kezelési stratégiájának meghatározása.

Kulcsszavak: iszkémiás szívbetegség, stabil angina pectoris, optimális gyógyszeres kezelés

Revascularization or optimal medical therapy in stable coronary artery disease. Which strategy to follow? Defining optimal management of patients with stable, ischemic heart disease is still a central area of debate. All patients with coronary artery disease should at least be managed with optimal medical therapy, many patients with stable coronary artery disease continue to be treated with revascularization, whether by percutaneous coronary intervention or coronary artery bypass grafting. It remains unclear is whether revascularization further improves prognosis when added to optimal medical therapy. In the present summary we start by reviewing the definition and details of optimal medical therapy and then to review the results of randomized trials comparing both revascularization strategies with optimal medical therapy. We conclude that revascularization and medical therapy should be used as complementary strategies. Which strategy to follow? Hopefully the ongoing ISCHEMIA (International Study of Comparative Health Effectiveness with Medical and Invasive Approaches) trial will bring us closer to the answer which seeks to determine optimal management for patients with stable ischemic heart disease.

Keywords: ischaemic heart disease, stable angina, optimal medical therapy

\section{Bevezető}

A kardiovaszkuláris betegségek továbbra is vezető haláloki tényezők, ezen belül az iszkémiás szívbetegség a mortalitás fő oka. A koronáriabetegség az életkor elörehaladtával egyre gyakoribbá válik, a betegek kezelése egyre nagyobb terhet ró az egészségügyre, ezért a stabil koszorúér-betegség optimális kezelési stratégi- áának kérdése napjainkban egyre nagyobb hangsúlyt kap. A stabil koszorúér-betegség kezelésében számos módszert alkalmaznak és hasonlítottak össze. Ilyen a perkután transzluminális koronária-angioplasztika (PTCA), a perkután koronária-intervenció (PCl), illetve a koronária bypass graft mütét (CABG). Ezek közül az elmúlt 10 évben a PCl terjedt el leginkább (1). 
A revaszkularizáció elsődleges célja, hogy csökkentse a mortalitást, a miokardiális infarktus bekövetkeztének valószínűségét, valamint az anginás panaszok csökkentésével hozzájáruljon az életminőség javulásához. Az, hogy az optimális gyógyszeres terápia mellett a revaszkularizáció valóban hozzájárul-e a stabil koszorúér-betegségben a mortalitás csökkentéséhez, továbbra is kérdéses.

\section{Az optimális gyógyszeres terápia stabil iszkémiás szívbetegségben}

Stabil angina pectorisban az optimális konzervatív kezelés olyan átfogó, szekunder prevenciós tevékenységet jelent, ahol az optimalizált gyógyszeres terápiának és életmód-változtatásnak köszönthetően csökken a kardiovaszkuláris események bekövetkezésének esélye, valamint javul az életminőség. Egészen 1995-ig nem publikáltak a szekunder prevencióval kapcsolatos irányelvet, akkoriban a gyógyszeres terápiás ajánlások az akut koronária szindrómát elszenvedő betegekre korlátozódtak, az életmódbeli változtatások pedig szinte kizárólag a dohányzás elhagyásának szükségességét hangsúlyozták. 2001-től a béta-blokkolók és az angiotenzinreceptor-blokkolók (ACE-gátlók) kezdtek szélesebb körben elterjedni, ezt követte annak felismerése, hogy fontos a dyslipidaemiák korai kezelése, így a statinok széles körü alkalmazása. Később egyre nagyobb hangsúlyt kapott a diéta, testsúlymérséklés és testmozgás fontossága, valamint a cukorbetegség és hipertónia szoros kontrollja. Lehetőség szerint minden betegnek aszpirint kell szedni, alternatív megoldásként a clopidogrel alkalmazható. Annak ellenére, hogy ma már a stabil iszkémiás szívbetegség kezelésében az „up-to-date” ajánlások könnyen és széleskörüen elérhetőek, gyakorlati alkalmazásuk nem minden esetben valósul meg és a betegek az irányelvhez képest csökkent adherenciát mutatnak (2).

A stabil koronáriabetegség gyógyszeres kezelésének két fő célja az anginás fájdalom csökkentése, ezzel az életminőség javítása, valamint a kardiovaszkuláris mortalitás mérséklése.

Abban az esetben, ha a páciensnél koronáriabetegség lehetőségét feltételezzük, minél korábban javasolt az antianginás terápia bevezetése. A terápiás lépések célja a tünetek csökkentése, a terhelés indukálta panaszok kivédése (3). Az elsőként választandó antianginás szert a beteg individuális paraméterei alapján érdemes megválasztani, figyelembe véve a társbetegségeket és lehetséges mellékhatásokat. Az irányelvek alapján a megfelelő antianginás terápia legalább két, eltérő hatásmechanizmussal rendelkező gyógyszert tartalmaz. A nitrátok, a béta-blokkolók és a kalciumantagonisták képezik a három fö gyógyszercsoportot a stabil koszorúér-betegség tüneti kezelésében. Az antianginás terápia indításakor a beteg vérnyomására és szívfrekvenciájára különös figyelmet kell fordítani.

Minden betegnek sublingualisan alkalmazható, rövid hatású nitroglicerin-tartalmú készítménnyel kell rendelkeznie, emellett természetesen a hosszú hatású nitrát készítmények is alkalmazhatóak az anginás panaszok kivédésére. A béta-blokkolók alkalmazása a stabil koszorúér-betegség tüneti kezelésének alapját képezik. Nem hipertóniás, stabil koszorúérbetegek esetén is elsőként választandók. Az antianginás hatás hátterében a béta-blokkolók negatív chronotrop és inotrop hatása áll, a frekvencia csökkentésével a szívizomzat oxigénszükségletét mérséklik. A béta-blokkolók hatására a diasztolé ideje megnyúlik, a nem iszkémiás területeken a vaszkuláris rezisztencia emelkedik, így javul a perfúzió és a kontraktilitás a szívizomzat hibernált területein (4). Az Európai Kardiológus Társaság (ESC) aktuális irányelvében a béta-blokkolókat elsővonalbeli szerként javasolt alkalmazni a frekvencia csökkentésére és a tünetek enyhítésére (I. osztályú A-evidenciaszint). A béta-blokkolók alkalmazhatók tünetmentes betegeknél is, ahol nagy kiterjedésü iszkémia detektálható, továbbá mikrovaszkuláris angina esetén, a terhelés kiváltotta panaszok mérséklésére $(5,6)$. A béta-blokkolók bizonyítottan növelik a beteg terhelhetőségét, megnyújtják az iszkémia kialakulásáig eltelt időt, valamint csökkentik a panaszos és tünetmentes anginás epizódok számát $(7,8)$. Placebokontrollált, randomizált vizsgálatok aktuális adatai alapján stabil koronáriabetegeknél, akik korábban miokardiális infarktust nem szenvedtek el, a béta-blokkolóknak mortalitáscsökkentő hatás nincs $(9$, 3). Béta-blokkolókkal készült releváns klinikai vizsgálatok metaanalízise sem mutat szignifikáns javulást a mortalitás tekintetében, azonban a kardioszelektív béta-blokkolók csoportjában a túlélés javítása irányába javuló tendencia mutatkozik (10). 50-60 percenkénti, nyugalmi pulzusszám az ideális koszorúér-betegségben. Elsősorban a kardioszeletív béta-blokkolók javasoltak, így minimalizálhatjuk a nemkívánatos mellékhatások előfordulását, mint például a bronchokonstrikciót, amely béta-2-antagonizmus által mediált folyamat. Optimálisnak mondható gyógyszer a bisoprolol, amely egy kifejezetten kardioszelektív béta-blokkoló, a béta 1-es receptorokhoz való szenzitivitása 120-szor nagyobb, mint a béta-2-receptorokhoz. Napi 20 mg-os dózisban mutattak ki enyhe béta-2-blokkoló hatást, így a klinikumban biztonsággal alkalmazható. Intrinszik szimpatomimetikus aktivitása nincs, gasztrointesztinális felszívódása gyors és csaknem teljes, 50-50\%-ban választódik ki a vesén és a májon át. A bisoprololnak a stabil iszkémiás szívbetegségen kívül szívelégtelenségben is van indikációs köre. A kalciumantagonisták elfogadható alternatívát jelentenek olyan betegeknél, akik a béta-blokkolót nem tolerálják, vagy béta-blokkoló mellett is panaszosak maradnak, ilyen esetben akár béta-blokkolóval is kombinálhatóak, kellő odafigyeléssel. A dihidropiridin és non-dihidropiridin típusú kalciu- 
mantagonisták csökkentik a szív oxigénigényét és hatékonyan mérséklik az anginás panaszokat, egyedül a nifedipin kerülendő, mivel dózisfüggő módon növelheti a mortalitást koszorúér-betegségben (11). Amennyiben a beteg megfelelő szívfrekvenciáját feltitrált béta-blokkoló mellett sem tudjuk elérni, vagy annak használata kontraindikált, ivabradint alkalmazhatunk. Főként szívelégtelenséggel szövődött koszorúér-betegségben alkalmazhatjuk biztonsággal (3), előnye, hogy nem befolyásolja a vérnyomást és a szívizomzat kontraktilitását. Az antianginás terápia dózisát elsősorban a panaszok alakulása határozza meg, azonban a vérnyomás és a pulzusszám célértékre történő beállítása is fontos. Vérnyomás tekintetében, amennyire a körülmények engedik a 120/85 Hgmm (12), vagy az alatti érték az elfogadható, pulzus tekintetében pedig a korábbiakban már említett 60/min alatti szívfrekvencia a cél. Amennyiben a tünetek a terápia indításától számított két héten belül nem szünnek, koronarográfia megfontolandó.

A stabil koszorúér-betegség kezelésében a tüneti szerek mellett a mortalitást kedvezően befolyásoló gyógyszercsoportok a trombocitaaggregáció-gátlók, a statinok, az ACE-gátlók és angiotenzinreceptor-blokkolók. Stabil koszorúér-betegség gyanúja esetén minél korábban acetilszalicilsav indítása javasolt (13). Az elsődleges végpontok metaanalízise során bebizonyosodott, hogy a kardiovaszkuláris események előfordulása 18\%kal, a miokardiális infarktus előfordulása 23\%-kal alacsonyabb azoknál a betegeknél, akik aszpirint szednek, szemben a placebocsoporttal (13). Az aszpirin elfogadott napi adagja 75-150 mg (6). Közepes vagy nagy intenzitású statin (atorvastatin $80 \mathrm{mg}$, rosuvastatin 40 mg) adása minden páciens számára javasolt, amenynyiben kontraindikáció nem áll fenn. Az LDL-koleszterinszint célértéke 1,8 mmol/liter alatti legyen, illetve a kiindulási érték legalább $50 \%$-os csökkentése javasolt, amennyiben a célértéket nem sikerült elérni. A stabil koronáriabetegségben alkalmazható emelt dózisú statin és lipidszintcsökkentő kezelés sematikus ábrázolását az 1. ábra mutatja, amelyben napjainkban már az evolocumab is helyet kaphat. Az ACE-gátlók alkalmazása szintén javasolt koszorúér-betegségben, főként, ha csökkent balkamra-funkcióval, hipertóniával, cukorbetegséggel, vagy vesebetegséggel társul (6). ACE-gátló intolerancia esetén természetesen ARB javasolt.

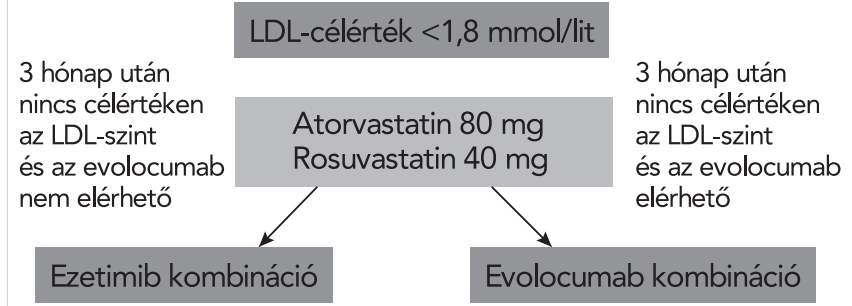

1. ÁBRA. Az optimális gyógyszeres kezelés során alkalmazható terápiás stratégia az ISCHEMIA-vizsgálatban az LDL-koleszterinszint-célérték elérésére

\section{A gyógyszeres terápia és revaszkularizáció összehasonlítása - Irodalmi adatok, az ISCHAEMIIA-vizsgálat}

Az első vizsgálatok az 1970-es évekig nyúlnak viszsza, amelyekben a gyógyszeres terápiát hasonlították össze a bypass-műtéttel. Az eredmények túlnyomó része nem mutatott szignifikáns különbséget az összmortalitás, a kardiovaszkuláris mortalitás, valamint a miokardiális infarktus tekintetében. A vizsgálatoknak számos hátránya volt, ilyen a strukturált terápia hiánya, illetve, hogy a gyógyszerek nem voltak céldózisra titrálva, valamint az ACE-gátlók, a trombocitaaggregáció-gátlók és a statinok még nem voltak elérhetőek ebben az időben. Az utolsó nagy vizsgálat, amely a CABG-mútétet hasonlította össze az optimális gyógyszeres kezeléssel a 2011-ben publikált STICH-vizsgálat volt (Surgical Treatment for Ischemic Heart Failure) (14). A tanulmányba 35\% alatti ejekciós frakcióval bíró betegeket vontak be és randomizáltak bypass-mütét és gyógyszeres terápia, valamint kizárólag gyógyszeres terápia csoportba. Az 50\%-nál nagyobb bal közös törzs szükület, illetve az antianginás terápia mellett jelentkező CCS III-IV angina kizárást jelentett a vizsgálatból. A vizsgálat eredménye nem mutatott szignifikáns különbséget az összmortalitás tekintetében a két csoport között (14).

Mivel a $\mathrm{PCl}$ a legelterjedtebb revaszkularizációs módszer, nagyon fontos definiálni, hogy a kemény végpontok és a tünetek csökkentése szempontjából pontosan melyik betegcsoport profitál a leginkább a beavatkozásból. Szintén nem elhanyagolható a beavatkozás költséghatékonyságának meghatározása, hiszen minimalizálni kell a szükségtelen revaszkularizációk számát. A legnagyobb betegszámú és jelentőségű vizsgálat, amely a $\mathrm{PCl}$-t és az optimális gyógyszeres terápiát összehasonlította a COURAGE- (Clinical Outcomes Utilizing Revascularization and Aggressive Drug Evaluation) vizsgálat volt (15). A vizsgálatba 2287, legalább egyér-betegségben szenvedő, stabil koronáriabeteget vontak be $(70 \%$-os proximális szükület és az iszkémia EKG-jelei, vagy $80 \%$-os stenosis és pozitív terheléses EKG) és randomizálták vagy kizárólag optimális gyógyszeres terápia karra, vagy $\mathrm{PCl}$ és optimális gyógyszeres terápia karra. A gyógyszeres terápiának tartalmaznia kellett aszpirint vagy clopidogrelt, béta-blokkolót önmagában, vagy kombinációban nitráttal és kalciumcsatorna-blokkolóval, továbbá ACE-gátlót vagy ARB-t, illetve statint. Az elsődleges végpont az összhalálozás, vagy a nem fatális miokardiális infarktus volt. 4,6 év átlagos utánkövetés során a kumulatív elsődleges események előfordulása a $\mathrm{PCl}$-csoportban $19 \%$ volt, míg az optimális gyógyszeres csoportban 18,5\% $(p=0,06)$ (2. ábra). Az előre meghatározott összetett végpontok tekintetében (halál, nonfatális miokardiális infarktus, cerebrovaszkuláris esemény, vagy hospitalizáció instabil angina miatt) nem volt különbség a két csoport kö- 

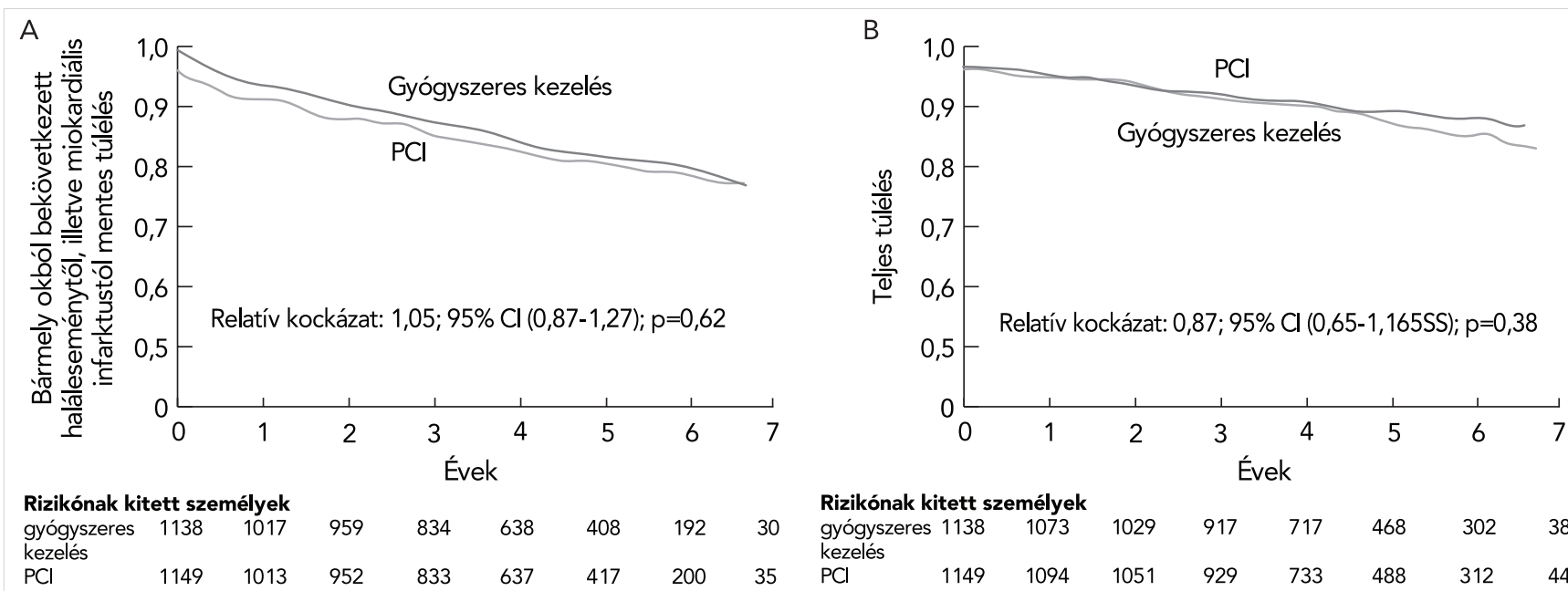

2. ÁBRA. A Kaplan-Meier túlélési görbe szemléltetése a COURAGE-vizsgálatban. A: Miokardiális infarktus és bármely okból bekövetkezett haláleset tekintetében. B: Összmortalitás tekintetében (15)

zött. A PCl-csoportban viszont szignifikánsan csökkent az anginás panaszok száma, amely öt év után szintén kiegyenlítődött. A COURAGE-vizsgálat előnye a korábbi tanulmányokhoz viszonyítva a betegek megfelelő adherenciája volt a gyógyszeres terápiához, a betegek több, mint 90\%-a aszpirinterápián volt, $80 \%$ béta-blokkolót szedett és több, mint $70 \%$ volt ACE-gátló, vagy ARB-terápián.

A revaszkularizáció és gyógyszeres terápia összehasonlításában végzett vizsgálatok harmadik csoportját azok a tanulmányok alkotják, ahol a betegeknél a $\mathrm{PCl}$ és a CABG is össze lett hasonlítva, továbbá a két invazív stratégia az optimális gyógyszeres kezeléssel. A legjelentősebb és legnagyobb populációval bíró vizsgálat a BARI 2D (Bypass Angioplasty Revascularization Investigation 2 Diabetes) tanulmány (16). 2368 2-es típusú diabéteszes beteget vontak be a vizsgálatba, ahol angiográfia alapján állították fel a koszorúér-betegség diagnózisát, ezt követően a betegek vagy

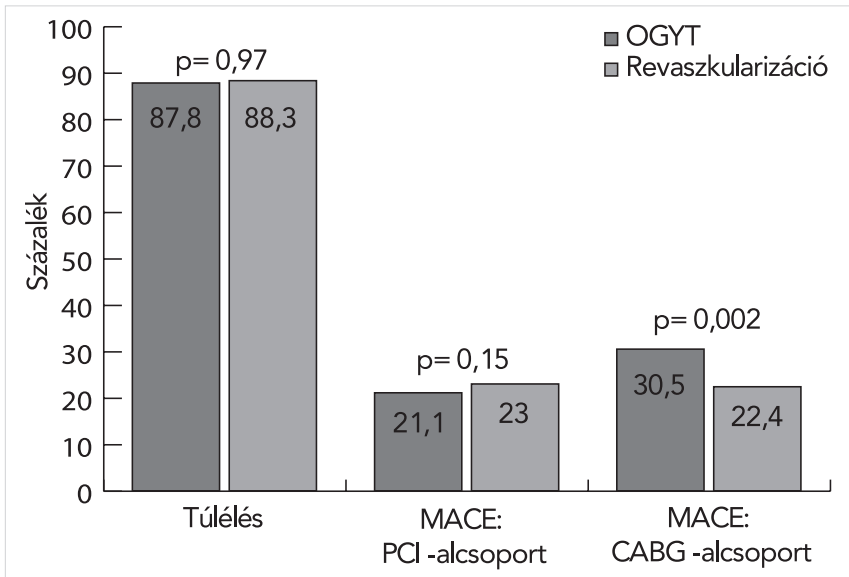

3. ÁBRA. Túlélés és a nagy kardiovaszkuláris események előfordulása a BARI 2D-vizsgálatban (16) optimális gyógyszeres kezelést kaptak, vagy azonnali CABG-mútétet vagy PCl-t végeztek. A betegek antidiabetikus terápiáját is revizionálták, optimalizálták (inzulin alkalmazása, vagy inzulin-szenzitizáció). Az elsődleges végpont az összhalálozás volt, a másodlagos végpont pedig az összetett halálozás, a miokardiális infarktus, vagy cerebrovaszkuláris esemény. Az átlagos 5,3 éves utánkövetés során a revaszkularizáció és optimális gyógyszeres terápiacsoport a halálozás szempontjából nem különbözött egymástól és nagy kardiovaszkuláris események szempontjából sem volt szignifikáns különbség. A CABG-alcsoportban viszont szignifikánsan alacsonyabb volt a jelentős nemkívánatos kardiovaszkuláris események előfordulása a gyógyszeres terápiához viszonyítva. A szerzők következtetése alapján a halálozás és a nagy kardiovaszkuláris események előfordulásában nincs különbség a revaszkularizáció és az optimális gyógyszeres terápiacsoportban (3. ábra).

A Mancini és munkatársai által végzett metaanalízisben (17) három nagy klinikai vizsgálatot tanulmányoztak (BARI 2D, COURAGE, FREEDOM). Az eredmények alapján 2-es típusú cukorbetegségben klinikai evidencia, hogy a legjobb terápiás stratégia a bypass-mútét, optimális gyógyszeres kezeléssel kombinálva (4. ábra). A CABG és optimális gyógyszeres kezeléscsoportban az 5 éves utánkövetés során egyértelműen csökkent a betegek összhalálozása, a miokardiális infarktus és a stroke előfordulása, szemben a $\mathrm{PCl}$ és gyógyszeres terápián vagy kizárólag gyógyszeres terápián lévő csoporttal. Amennyiben a klinikai gyakorlat során a CABG-műtétnek kontraindikációja áll fenn, második opcióként a gyógyszeres terápia javasolt és csak akkor szükséges koronária-intervenciót végezni, ha a beteg anginás panaszai nem szűnnek és életminőségét befolyásolják (17).

A fent említett vizsgálatok többsége az optimális gyógyszeres terápiát javasolja, mint elsődleges terápiás stratégiát stabil koszorúér-betegségben akkor, ha a bal közös 


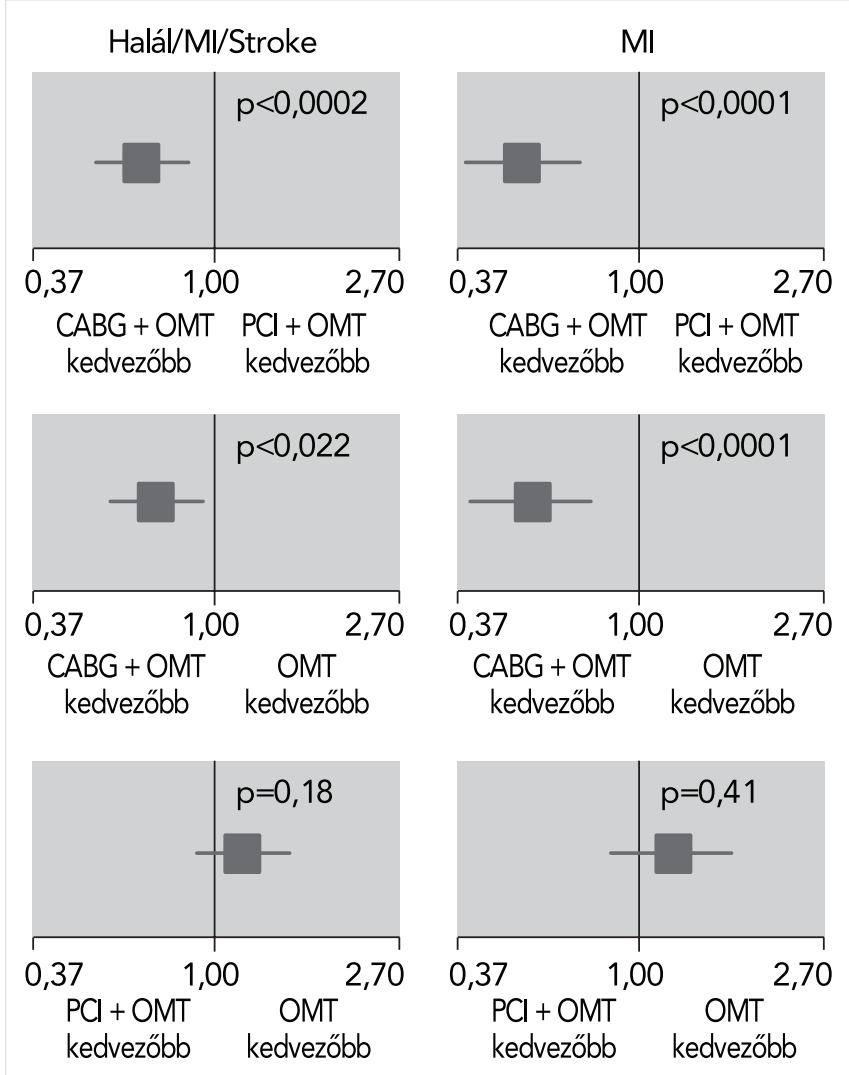

4. ÁBRA. A 2-es típusú cukorbetegségben szenvedő koronáriabetegek revaszkularizációs stratégiája (17), 5 éves kockázati aránnyal számolva

törzs szűkülete nem áll fenn, azonban számos metaanalízis más eredményt mutatott. Egy 2008-ban megjelent tanulmányban Scömig és munkatársai 20\%-os mortalitáscsökkenést mutattak ki a PCl-csoportban, szemben az optimális gyógyszeres terápián lévő populációval (18). Egy másik metaanalízisben Jeremias és munkatársai szintén a revaszkularizáció előnyét állapították meg a mortalitás tekintetében, az optimális gyógyszeres kezeléssel szemben, azonban nem volt különbség a nonfatális infarktus előfordulásában a két csoport között (19). Allmann és munkatársai olyan iszkémiás szívbetegeket vontak be, ahol balkamra-diszfunkció állt fenn és noninvazív vizsgálatokkal a viabilitást mérték fel. Az eredmények kimutatták, hogy viabilitás jelenléte esetén végzett revaszkularizáció egyértelműen jobb túlélést eredményez. Az említett metaanalízisek alapján megállapítható, hogy nem egyértelmű a revaszkularizáció és az optimális gyógyszeres terápia szerepe stabil iszkémiás szívbetegségben. A kérdések megválaszolásában nagy valószínúséggel a jelenleg is folyamatban lévő ISCHEMIA (International Study of Comparative Health Effectiveness with Medical and Invasive Approaches) vizsgálat segíteni fog (20). Stabil, panaszos, noninvazív vizsgálatokkal dokumentált iszkémiával rendelkező betegek kerülnek beválogatásra. A megfelelő vesefunkciójú (GFR nagyobb $60 \mathrm{ml} / \mathrm{min}$ ) betegeken koronária
CT-vizsgálatot végeznek. Amennyiben a CT-vizsgálaton az obstruktív koronáriabetegség megállapítható, illetve a bal közös törzs szűkülete kizárható, randomizálásra kerül sor, ahol a beteg vagy kizárólag optimális gyógyszeres terápiát kap, vagy $\mathrm{PCl}$, illetve CABG-mütét történik. A vizsgálat speciális alcsoportjában csökkent vesefunkcióval bíró, illetve dializált stabil koronáriabetegeket vonnak be (ISCHEMIA CKD). A vizsgálat elsődleges végpontja a kardiovaszkuláris halálozás vagy nem a fatális miokardiális infarktus. Másodlagos végpont az életminőség alakulása, a költséghatékonyság és a kardiovaszkuláris okból történő hospitalizáció. Mivel csak szignifikáns iszkémia kimutatása után lehet randomizálni a betegeket, a vizsgálat remélhetőleg segíti az optimális kezelési stratégia megválasztását.

\section{Következtetések}

Napjainkban jelentős mennyiségű adat áll rendelkezésre az optimális gyógyszeres terápiáról és a revaszkularizációról stabil koronáriabetegségben, azonban számos kérdés még mindig megválaszolatlan maradt. A koronáriabetegség prevalenciájának emelkedése, valamint a kezelés anyagi vonzatának növekedése arra ösztönözi a klinikusokat és kutatókat, hogy megtalálják az optimális terápiás stratégiát.

Az már világossá vált, hogy az optimális gyógyszeres terápia alkalmazásával kezdjük a betegek kezelését, azonban a klinikai gyakorlatban, az esetek jelentős részében az irányelvek által meghatározott terápiás célok és az elvárható compliance sajnos nem valósul meg. Továbbá tisztázatlan maradt, hogy a gyógyszeres kezelés megkezdése után, vajon minden betegnél szükséges-e rutinszerüen a revaszkularizáció, illetve csak jól definiált esetekben van létjogosultsága. $A z$ evidenciák alapján megállapíthatjuk, hogy a revaszkularizáció csökkenti a beteg panaszait, viszont a mortalitásra, vagy a miokardiális infarktus előfordulásának csökkenésére nincs hatással. Nagy reményt füzünk az ISCHEMIA-vizsgálat eredményeihez, amely nagy valószínűséggel közelebb visz az optimális gyógyszeres terápia megválasztásához stabil iszkémiás szívbetegségben.

\section{Irodalom}

1. Epstein AJ, Polsky D, Yang F, Yang L, Groeneveld PW. Coronary revascularization trends in the United States, 2001-2008. Jama 2011; 305: 1769-76. DOI: 10.1001/jama.2011.551

2. Smith SC, Jr., Blair SN, Bonow RO, et al. AHA/ACC Scientific Statement: AHA/ACC guidelines for preventing heart attack and death in patients with atherosclerotic cardiovascular disease: 2001 update: A statement for healthcare professionals from the American Heart Association and the American College of Cardiology. Circulation 2001; 104: 1577-9. DOI: 10.1161/hc3801.097475

3. Husted SE, Ohman EM. Pharmacological and emerging therapies in the treatment of chronic angina. Lancet 2015; 386: 691-701. DO 10.1016/S0140-6736(15)61283-1 
4. Dezsi CA, Szentes V. The Real Role of beta-Blockers in Daily Cardiovascular Therapy. American journal of cardiovascular drugs: drugs devices, and other interventions 2017. DOI: 10.1007/s40256-017-0221-8 5. Rosendorff C, Lackland DT, Allison M, et al. Treatment of hypertension in patients with coronary artery disease: a scientific statement from the American Heart Association, American College of Cardiology, and American Society of Hypertension. Hypertension 2015; 65: 1372-407. DOI: 10.1161/HYP.0000000000000018

6. Task Force M, Montalescot G, Sechtem U, et al. 2013 ESC guidelines on the management of stable coronary artery disease: the Task Force on the management of stable coronary artery disease of the European Society of Cardiology. European heart journal 2013; 34: 2949-3003. DOI: 10.1093/eurheartj/eht296

7. Fox KM, Mulcahy D, Findlay I, Ford I, Dargie HJ. The Total Ischaemic Burden European Trial (TIBET). Effects of atenolol, nifedipine $\mathrm{SR}$ and their combination on the exercise test and the total ischaemic burden in 608 patients with stable angina. The TIBET Study Group. European heart journal 1996; 17: 96-103.

8. van de Ven LL, Vermeulen A, Tans JG, et al. Which drug to choose for stable angina pectoris: a comparative study between bisoprolol and nitrates. International journal of cardiology 1995; 47: 217-23. 9. Bangalore S, Bhatt DL, Steg PG, et al. beta-blockers and cardiovascular events in patients with and without myocardial infarction: post hoc analysis from the CHARISMA trial. Circulation Cardiovascular quality and outcomes 2014; 7: 872-81. DOI: 10.1161 CIRCOUTCOMES.114.001073

10. Huang HL, Fox KA. The impact of beta-blockers on mortality in stable angina: a meta-analysis. Scottish medical journal 2012; 57: 69-75.

11. Furberg CD, Psaty BM, Meyer JV. Nifedipine. Dose-related increase in mortality in patients with coronary heart disease. Circulation 1995; 92: 1326-31.

12. Group SR, Wright JT, Jr., Williamson JD, et al. A Randomized
Trial of Intensive versus Standard Blood-Pressure Control. The New England journal of medicine 2015; 373: 2103-16. DOI: 10.1056/NEJ Moa1511939

13. Cornell J. Aspirin in the primary prevention of vascular disease. Lancet 2009; 374: 878-9; author reply 879. DOI: 10.1016/S0140. 6736(09)61623-8

14. Velazquez EJ, Lee KL, Deja MA, et al. Coronary-artery bypass surgery in patients with left ventricular dysfunction. The New England journal of medicine 2011; 364: 1607-16. DOI: 10.1056/NE. Moa1100356

15. Boden WE, O'Rourke RA, Teo KK, et al. Optimal medical therapy with or without $\mathrm{PCl}$ for stable coronary disease. The New England journal of medicine 2007; 356: 1503-16. DOI: 10.1056/NEJ Moa070829

16. Group BDS, Frye RL, August P, et al. A randomized trial of therapies for type 2 diabetes and coronary artery disease. The New England journal of medicine 2009; 360: 2503-15. DOI: 10.1056/NEJ Moa0805796

17. Mancini GB, Farkouh ME, Brooks MM, et al. Medical Treatment and Revascularization Options in Patients With Type 2 Diabetes and Coronary Disease. Journal of the American College of Cardiology 2016; 68: 985-95. DOI: 10.1016/j.jacc.2016.06.021

18. Schomig A, Mehilli J, de Waha A, Seyfarth M, Pache J, Kastrati A. A meta-analysis of 17 randomized trials of a percutaneous coronary intervention-based strategy in patients with stable coronary artery disease. Journal of the American College of Cardiology 2008; 52: 894-904.

\section{DOI: 10.1016/j.jacc.2008.05.051}

19. Jeremias A, Kaul S, Rosengart TK, Gruberg L, Brown DL. The impact of revascularization on mortality in patients with nonacute coronary artery disease. The American journal of medicine 2009; 122: 152-61. DOl: 10.1016/j.amjmed.2008.07.027

20. Hochman J MDftltl, effectiveness Isoch, progress. wmaiaSi, www.ischemiatrial.org

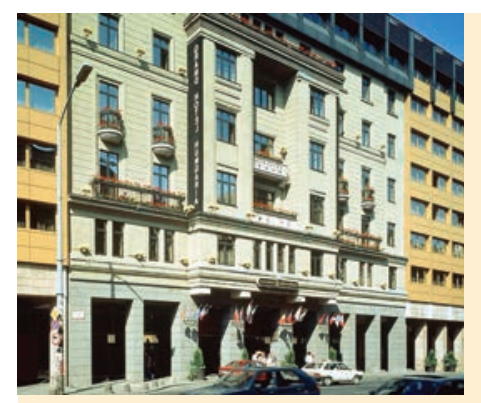

VII. Magyar Kardiovaszkuláris Konszenzus Konferencia

\section{Kongresszus időpontja: 2017. 12. 01. péntek Regisztrációs határidő: 2017. 11. 13. (www.eqcongress.hu)}

A konferencián való részvétel térítésmentes, de jelentkezéshez kötött.

A VII. Magyar Kardiovaszkuláris Konszenzus Konferenciára 2017. december 1-jén 09.00-16.00 óra között Budapesten a Hotel Hungaria City Centerben (1074 Budapest, Rákóczi út 90.) kerül sor.

A Konszenzus Konferencia szerves folytatása a korábbiaknak. Magyarországon először 2003-ban szerveztük meg az I. Kardiovaszkuláris Konszenzus Konferenciát, számos orvosi tudományos társaság részvételével. A konferenciák áttekintették a kockázatbesorolás aktuális helyzetét, az életmód változtatás lehetőségeit, és ajánlásokat fogalmaztak meg nagy kockázati tényezők kívánatos célértékeinek elérésére, valamint a kuratív, preventív és protektív gyógyszeres és egyéb kezelésre vonatkozóan. A VII. Konferencia előkészítésére a Tudományos Szervező Bizottság - a társaságok képviselőivel ez év októberében tartott - Kerekasztal Konferencián alakította ki a 2017. évi irányelvek lényegét, amelyet közmegegyezéssel terjesztünk a decemberi Konszenzus Konferencia elé. A konferencián résztvevők előadásokat hallhatnak az elmúlt három esztendő új vizsgálati eredményeiről, illetve ezek alapján javaslatot tesznek szakterületük ajánlásaira. A konferencia anyagát színes poszteren sokszorosítjuk, orvosi folyóiratokban, kongresszusokon ismertetjük. Olyan ajánlást szeretnénk közreadni, amely valamennyi orvoslásban tevékenykedő szakember számára vezérfonal lehet.

\section{Prof. dr. Szollár Lajos \\ A MAT tiszteletbeli elnöke a Konferencia elnöke}
Prof. dr. Karádi István a MOTESZ elnöke A Konferencia Társelnöke

\author{
Prof. dr. Paragh György \\ A MAT elnöke \\ a Konferencia Társelnöke
}

